\title{
Comparative assessment of root canal preparation by undergraduate students using manual and automated devices
}

\author{
Avaliação comparativa do preparo do canal radicular realizado \\ por alunos de graduação com os sistemas manual e oscilatório
}

\begin{abstract}
Purpose: To evaluate the preparation of root canals performed by undergraduate students using manual and automated devices, based on the amount of dentin removed from the canal walls, the time required for preparation, and students' opinions.

Methods: Mesial roots of 20 human mandibular molars extracted for clinical reasons were used in the experiment. Twenty undergraduate students prepared two canals each, one using the manual method and the other using an automated device; following root canal preparation, the students filled out a questionnaire. Time was recorded throughout the procedures. Teeth were scanned with computed tomography before and after preparation. Images were superimposed and measured for the amount and area of dentin removed.

Results: There was no difference between the use of manual and automated devices with regard to the amount of material removed. Distal walls presented a greater amount of material removed from the cervical third when compared with middle third in both techniques. There were no statistically significant differences between both techniques with regard to preparation time.

Conclusion: The automated system represents an adequate alternative option as an auxiliary resource for undergraduate teaching in the preparation of root canals.
\end{abstract}

Key words: Endodontics; instrumentation; root canal therapy; X-ray computed tomography

\section{Resumo}

Objetivo: Avaliar o preparo do canal radicular realizado por alunos de graduação com os sistemas manual e oscilatório, considerando o desgaste produzido nas paredes do mesmo, o tempo de trabalho e a opinião dos estudantes.

Metodologia: Foram utilizadas raízes mesiais de 20 molares inferiores humanos extraídos por indicação clínica. Vinte alunos de graduação realizaram o preparo de dois canais, um deles com o sistema manual e o outro com o sistema oscilatório, e posteriormente responderam a um questionário. O tempo foi registrado durante os preparos. Os dentes foram examinados por tomografia computadorizada antes e após o preparo. As imagens foram sobrepostas e as áreas de contorno demarcadas. Medidas lineares e da área de desgaste foram realizadas.

Resultados: Não houve diferença entre as técnicas quanto à medida linear de desgaste. A parede distal apresentou maior desgaste no terço cervical do que no médio em ambas as técnicas. A área total de desgaste foi maior no terço cervical do que no médio. Com relação ao tempo de preparo, não houve diferença estatisticamente significante entre as duas técnicas.

Conclusão: $O$ sistema oscilatório constitui-se em um recurso auxiliar para o preparo do canal radicular no ensino de graduação.

Palavras-chave: Endodontia; instrumentação; tratamento do canal radicular; tomografia computadorizada por raios-X

\author{
Andréa Cabral de Mello Vanzin a \\ Fernando Branco Barletta ${ }^{b, c}$ \\ Vania Fontanella ${ }^{b, d}$
}

- Pontifical Catholic University of Rio Grande do Sul (PUCRS), Porto Alegre, RS, Brazil

b Lutheran University of Brasil (ULBRA), Canoas, RS, Brazil

c University of Santa Cruz do Sul (UNISC), Santa Cruz do Sul, RS, Brazil

d Federal University of Rio Grande do Sul (UFRGS),

Porto Alegre, RS, Brazil

\author{
Correspondence: \\ Vania Regina Camargo Fontanella \\ Rua Coronel Paulino Teixeira, 169/403 \\ Porto Alegre, RS - Brazil \\ 90420-160 \\ E-mail: vaniafontanella@terra.com.br
}




\section{Introduction}

Endodontics has faced significant evolution over the last few years, especially in the field of root canal preparation. Automated systems have been widely employed by dental professionals and have, more recently, been introduced in practical modules of undergraduate dental programs. Such automated devices reduce working time while maintaining preparation quality and are very simple to use.

Automated systems allow to control the amount of dentin removed from risk zones, as well as to direct the instrument to less accessible areas of the root canal (1). The main advantages associated with automated devices includes the following: no need for special files, possibility to enlarge the root canal space, possibility to obtain a more centralized surgical canal, and compatibility with any preparation technique employed (2). Moreover, some in vitro studies have found that automated systems are superior to manual systems in terms of working time and preparation quality (3-6).

Inexperienced operators have been shown to use continuous rotary systems successfully and to achieve better preparation results with the automated than with manual systems (7-12). In some countries, dental schools have already included the use of automated devices in undergraduate practical modules, an initiative that has had an impact on the teaching of Endodontics (13).

The objective of the present in vitro study was to compare, using multislice computed tomography, the amount of dentin removed from the canal walls as a result of root canal preparation by dental students, using both manual and automated devices (Adiel Super Endo 16, Adiel, Ribeirão Preto, SP, Brazil). The time required for preparation and the students' opinions on the experience were also assessed and discussed.

\section{Methods}

The study protocol was approved by the Research Ethics Committee at the Lutheran University of Brasil, Canoas, RS, Brazil. A total of 20 human mandibular molars extracted for clinical reasons, presenting intact, restored or partially destroyed crowns, were selected and stored in distilled water. In order to assure a homogeneous sample, all selected teeth had mesial roots with two distinct root canals, a length between 18 and $20 \mathrm{~mm}$, and curvature ranging between $15^{\circ}$ and $30^{\circ}$, according to the method described by Schneider (14).

After removal of the distal root, periapical radiographs were obtained in mesiodistal and buccolingual directions, followed by access to the pulp chamber and root canal exploration. Working length was determined visually at $1 \mathrm{~mm}$ from the root apex. Teeth were dried and stored in numbered vials.

Baseline root canal images were obtained using a multislice computed tomography equipment (Somaton Emotion Duo, Siemens, Erlangen, Germany), using the Specials
Dental mode, with 1-mm axial slice thickness and $0.1 \mathrm{~mm}$ increment, $130 \mathrm{kV}, 45 \mathrm{~mA}$ and bone tissue filter. Images were digitally stored and identified with the corresponding tooth number followed by B (baseline image, before root canal preparation).

Twenty undergraduate dental students who had already attended the disciplines Clinical Endodontics I and II at the Pontifical Catholic University of Rio Grande do Sul (PUCRS), Porto Alegre, RS, Brazil, but had no previous experience with the use of automated devices were randomly selected to prepare the root canals. All selected students agreed to participate in the study. Each student prepared one tooth with two root canals; one of the canals was prepared manually, and the other, using an automated device. Prior to the beginning of the experiment, students were provided with theoretical information on the use of automated devices and with a demonstration of their use in an extracted tooth. Before preparing the teeth included in the sample, students had the opportunity to become familiar with the kinematics of automated devices by preparing one extracted monoradicular tooth, following the standard technique.

Canals were prepared using manual and automated devices, with the step-back technique (15) and the anticurvature filing method (16). Preparation of all teeth was initiated with the mesiobuccal canal. Stainless steel, 21-mm long Flexofile files (Dentsply-Maillefer, Ballaigues, Vaud, Switzerland), sizes 15 to 45, were used in both groups. Each file was used in two root canals and then discarded.

Prior to preparation, teeth were soaked in distilled water for $48 \mathrm{~h}$, had their roots covered with gauze and fixed to a device. The cervical third was then prepared using GatesGlidden burs sizes 1 and 2. For the manual system, the first instrument used to working length was size 15 , followed by sizes 20,25 , and 30 . Then, instrument sizes 35,40 , and 45 were also employed, always reaching lengths $1 \mathrm{~mm}$ short of the previous size; file size 30 was used to working length at every instrument change at this phase.

In automated instrumentation, files were coupled to the Adiel Super Endo 16 rotary system, adapted to a lowrotation micromotor. The kinematics of the device consists of reciprocating right and left rotational movements with a rotary angle of $45^{\circ}$ and a 10:1 speed reduction. Prior to preparation, roots were manually explored with a file size 15. Then, the same instrumentation sequence used with the manual system was also employed with the rotary system. Throughout the experiment, $1 \%$ sodium hypochlorite was used with both systems, with a $10-\mathrm{mL}$ disposable syringe and a $25 \times 4$ hypodermic needle. Two milliliters of irrigant were used at every instrument change, followed by aspiration to $3 \mathrm{~mm}$ from the working length.

Instrumentation time was measured with a digital stopwatch started at the moment the first instrument was used and stopped after the use of the last instrument.

Each student filled out a questionnaire aimed to assess their impressions on the use of the automated system. The questionnaire comprised the following questions: (a) Which technique was easier to use?; (b) Did you face any difficulties 
while using the automated system? Please describe; and (c) Would you be interested in getting more training in automated instrumentation?

Following instrumentation, the root canal was aspirated and dried with absorbent paper points size 30 to the working length. Teeth were submitted to computed tomography once again, observing the same settings mentioned previously. Images were digitally stored and identified with the corresponding tooth number followed by A (final image, after root canal preparation). Images were inputed into E-Film ${ }^{\mathbb{B}}$ software (Merge Healthcare, Milwaukee, WI, USA), which allows to visualize the tooth in axial slices. Three images were selected for each tooth, corresponding to the cervical, middle and apical thirds, prior to and after preparation, and were saved as .jpg files at $4 \times$ magnification (Fig. 1).

The two images of the cervical third were opened in Adobe Photoshop $^{\circledR}$; the yellow color was used for the final image and blue was used for the baseline image. Images were superimposed, their filling was discarded, and the resulting image was increased in size. Guide lines were drawn at the most external pixel on the surface of anatomical and surgical root canals (Fig. 2); the distance between the two surfaces was measured in pixels. The same procedure was carried out with both root canals. Measurements were performed in duplicate in $30 \%$ of the images, resulting in an intraclass correlation coefficient of 0.986 .
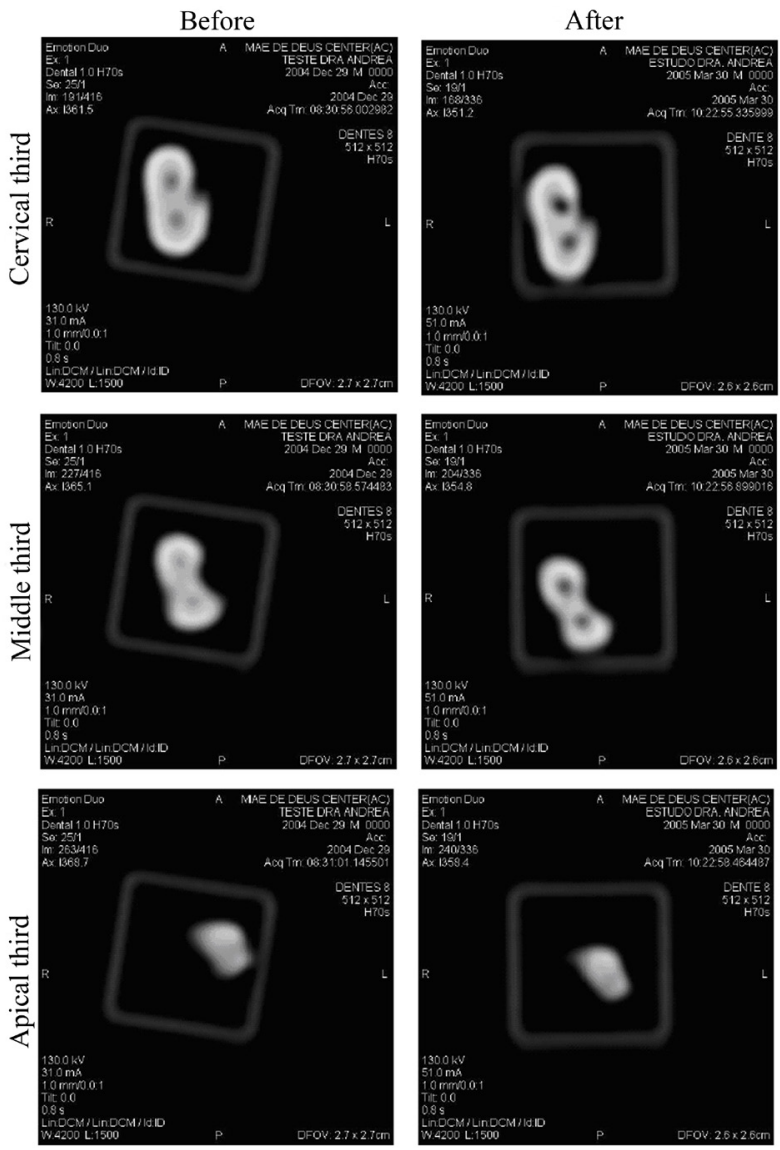

Fig. 1. Axial slices of the cervical, middle, and apical thirds, before and after preparation of the root canal walls.
Superimposed images were then edited using ImageLab ${ }^{\circledR}$ software (Universidade de São Paulo, São Paulo, SP, Brazil), in order to calculate the amount of dentin removed in pixels (Fig. 3).

Data on root canal surface wear was assessed using factorial analysis of variance, taking into consideration the following variables: system (manual vs. automated), canal third (cervical, middle, apical), and the interaction of the main effects (system + canal third), at the significance level of 5\%. The Student $t$ test for independent samples was used to compare the instrumentation time between the two systems.

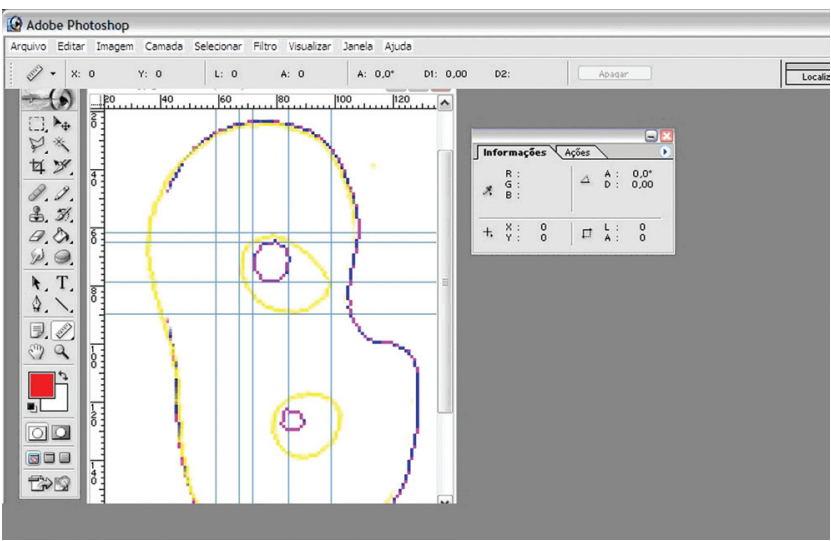

Fig. 2. Amount of dentin removed as measured by using the software Adobe Photoshop ${ }^{\circledR}$

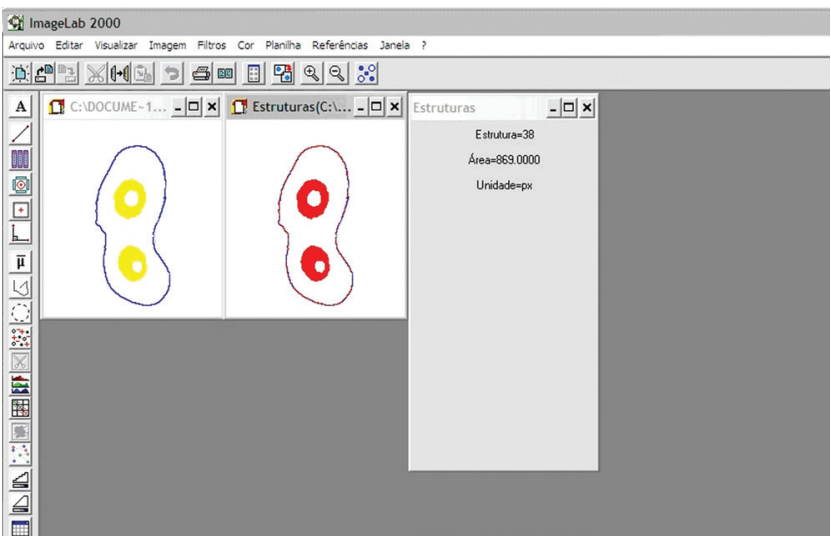

Fig. 3. Area of dentin removed as measured by using the software ImageLab ${ }^{\circledR}$.

\section{Results}

The amount of dentin removed (in pixels) in each of the four root canal surfaces is presented in Table 1. No significant differences were observed between the different techniques and thirds (cervical and middle) assessed in the buccal $(P=0.82)$, lingual $(P=0.17)$, and mesial surfaces $(P=0.22)$. In the distal surface, the cervical third presented an increased amount of material removed when compared with the 
Table 1. Comparison of the amount of dentin removed (in pixels) from the root canal walls, according to canal third and preparation system employed.

\begin{tabular}{|c|c|c|c|c|c|c|c|}
\hline \multirow[b]{2}{*}{ Variable } & \multicolumn{2}{|c|}{ Manual system } & \multicolumn{2}{|c|}{ Automated system } & \multirow[b]{2}{*}{ System } & \multicolumn{2}{|c|}{ P* } \\
\hline & $\begin{array}{l}\text { Middle third } \\
(n=14)\end{array}$ & $\begin{array}{l}\text { Cervical third } \\
(n=19)\end{array}$ & $\begin{array}{l}\text { Middle third } \\
\quad(n=14)\end{array}$ & $\begin{array}{l}\text { Cervical third } \\
(n=19)\end{array}$ & & Third & Interaction \\
\hline Surface & & & & & & & \\
\hline Buccal & $5.64 \pm 4.43$ & $5.79 \pm 3.39$ & $5.36 \pm 3.95$ & $4.79 \pm 3.46$ & 0.50 & 0.82 & 0.71 \\
\hline Lingual & $4.21 \pm 3.95$ & $6.32 \pm 3.61$ & $3.93 \pm 3.05$ & $4.21 \pm 3.17$ & 0.17 & 0.17 & 0.29 \\
\hline Distal & $4.36 \pm 2.76$ & $7.95 \pm 4.48$ & $4.50 \pm 3.72$ & $5.16 \pm 3.99$ & 0.17 & 0.03 & 0.13 \\
\hline Mesial & $3.93 \pm 2.02$ & $3.16 \pm 1.92$ & $3.36 \pm 2.71$ & $2.84 \pm 1.80$ & 0.40 & 0.22 & 0.81 \\
\hline $\begin{array}{l}\text { Area of dentin } \\
\text { removed }\end{array}$ & $190.1 \pm 104.5$ & $435.7 \pm 174.2$ & $184.4 \pm 96.2$ & $328.1 \pm 148.3$ & 0.11 & $<0.01$ & 0.15 \\
\hline $\begin{array}{l}\text { Total amount of } \\
\text { dentin removed }\end{array}$ & $18.1 \pm 9.6$ & $23.2 \pm 9.9$ & $17.1 \pm 9.4$ & $17.0 \pm 9.8$ & 0.14 & 0.31 & 0.29 \\
\hline
\end{tabular}

Data presented as mean \pm standard deviation.

* Statistical significance obtained in factorial analysis of variance.

middle third $(P=0.03)$, in both techniques. Considering the total amount of material removed in the four surfaces of the canal, no significant differences were found $(P=0.31)$ between the different techniques and thirds (cervical and middle) assessed. When analyzing the total area of material removed (in pixels), a significant difference was observed between the thirds, with a higher mean obtained for the cervical third when compared with the middle third $(P<0.01)$.

When comparing instrumentation time associated with the use of the two systems, the automated system was, on average, 3 minutes faster than the manual system $(15.61 \pm 4.4$ min vs. $18.35 \pm 7.5 \mathrm{~min})$. This difference, however, is not relevant enough to assert that one system was faster than the other.

The questionnaires filled out by the students revealed that $85 \%$ of them considered the automated devices easier to use than the manual system. In addition, $45 \%$ of the students reported difficulties related to loss of tactile sensitivity when using automated devices, and $100 \%$ of them manifested interest in undergoing further training in automated instrumentation.

\section{Discussion}

Dental professionals in general and Endodontics specialists in particular are increasingly using automated systems in the preparation of root canals. Therefore, it has been proposed that the introduction of practical modules with engine-driven devices in undergraduate programs would greatly improve the training of future professionals. The answers given by the students in our study confirmed such hypothesis: the great majority of them considered automated instrumentation to be easier and less tiring than manual instrumentation. On the other hand, preparation time was similar for both systems, differently from what has been reported in other studies $(9,10,12)$. However, some students reported that they felt insecure while using the automated system, which could be explained by the fact that they were using this type of device for the first time.
With regard to the methodology employed to assess both instrumentation systems, our aim was to find a noninvasive method which would allow to evaluate the amount of material removed from the canal walls in the three thirds of the canal. Image quality was poor in the apical third, which justified the exclusion of this third from the data analysis. This limitation was probably due to the resolution of our computed tomography device, which was unable to record small apical diameters due to partial volume effects; the same limitation has been reported previously $(9,17,18)$. Computed microtomography would have been an excellent alternative imaging method for the assessment of apical thirds, once it is able to record images with a resolution up to $20 \mu \mathrm{m}(19-22)$.

In our study, the amount of material removed from the distal wall of the root canal was $71 \%$ greater than that removed from the mesial surface, even when considering the total amount obtained for the two thirds; this finding is in agreement with other studies (7,20,23-25). Only one study (5) so far has observed a higher amount of dentin removed by automated devices on the external wall of the root canal, a fact that can be explained by the increased possibility offered by these devices to orient the instrument during anticurvature movements. In addition to the curvature of the mesial root and the tendency of stainless steel instruments to work tensioning the distal surface, this finding could be explained by the use of Gates-Glidden burs in the cervical third of the root canal.

The results obtained for the total area of material removed (cervical and middle thirds combined) showed a significant increase of the surgical root canal in relation to the anatomical canal in all cases, which was reported previously $(12,25,26)$. The area of material removed from the cervical third was greater than that removed from the middle third, which may be attributed to the use of Gates-Glidden burs sizes 1 and 2 during preparation of the cervical third. These burs correspond to instrument sizes 55 and 70, and have a larger caliber than the instruments employed in the middle third. Another aspect is dental anatomy per se, once the cervical third is significantly broader than the middle third. 
It is important to emphasize that, independently from the type of automated system used, manual exploration and refinement of the prepared canal are always necessary (3). The objective of automated systems is to reduce instrumentation time and to offer an easier, less tiring process for the operator - and the need to complement preparation with manual devices does not affect such advantages. Therefore, the use of reciprocating rotary instrumentation systems in undergraduate programs has been shown to be an excellent, low-cost alternative after training.

In summary, the use of automated systems by undergraduate students should be further explored. We believe that these devices are extremely beneficial and can be used successfully after adequate training. New studies should be conducted, with different assessment methodologies and a focus on the occurrence of root canal deviation. In addition, other instrumentation systems, e.g. continuous rotary systems used in association with nickel-titanium files, should also be assessed.

\section{Conclusions}

According to the methodology used in the present study, no differences were observed in the amount of material removed from the buccal, lingual, and mesial walls of the root canal in the three thirds assessed and with the two systems employed. Only the distal wall showed a significantly higher amount of dentin removed from the cervical third than the middle third, with both the manual and automated systems. The total area of material removed was significantly higher in the cervical third when compared with the middle third, and the automated system was, on average, 3 minutes faster than the manual system. These findings suggest that rotary systems are an adequate complementary tool and should therefore be included in the training of undergraduate students.

\section{References}

1. Sidney GB. Como preparar canal radicular com rapidez e eficiência. In: Cardoso RJ, Gonçalves EA. Endodontia trauma. São Paulo: Artes Médicas; 2002. v. 2, p. 189-218.

2. Sydney GB, Batista A, Melo LL, Mattos NH. Sistemas de rotação alternada em endodontia. J Bras Endod 2000;1:59-64.

3. Abou-Rass M, Ellis M. A comparison of three methods of hand and automated instrumentation using the CFS and M4 for preparations of curved and narrow simulated root canals. Braz Endod J 1996; 1 :25-33.

4. Batista A, Costa AL, Sydney GB, Melo LL, Mattos NH. Análise do preparo de canais simulados realizado manualmente e com sistema de rotação alternada com instrumentos de níquel-titânio. J Bras Endod 2003;4:25-32.

5. Borges PC, Schneider TK, Limongi O, Oliveira EM. Análise comparativa, in vitro, da atuação da instrumentação automatizada rotatória contínua e alternada nas paredes do canal radicular. J Bras Endod Period 2002;3:133-7.

6. Simi Junior J, Silva AH, Vaz JA. Avaliação morfológica comparativa do preparo de canais curvos, utilizando-se limas Flex-R, frente a duas técnicas de preparo: manual e Endo Gripper. Rev Odont UNICID 2002; 14:113-9.

7. Baumann MA, Roth A. Effect of experience on quality of canal preparation with rotary nickel-titanium files. Oral Surg Oral Med Oral Pathol 1999;88:714-8.

8. Namazikhah MS, Mokhlis HR, Alasmakh K. Comparison between a hand stainless-steel $\mathrm{K}$ file and a rotary NiTi 0.04 taper. J Calif Dent Assoc 2000;28:421-6.

9. Gluskin AH, Brown DC, Buchanan LS. A reconstructed computerized tomographic comparison of Ni-Ti rotary GT files versus traditional instruments in canals shaped by novice operators. Int Endod J $2001 ; 34: 476-84$

10. Sonntag D, Delschen S, Stachniss V. Root-canal shaping with manual and rotary $\mathrm{Ni}$-Ti files performed by students. Int Endod 2003;36:715-23

11. Hänni S, Schönenberger K, Peters OA, Barbakow F. Teaching an engine-driven preparation technique to undergraduates: initial observations. Int Endod J 2003;36:476-82.

12. Sonntag D, Guntermann A, Kim SK, Stachniss V. Root canal shaping with manual stainless steel files and rotary $\mathrm{Ni}$-Ti files performed by students. Int Endod J 2003;36:246-55.

13. Arbab-Chirani R, Vulcain JM. Undergraduate teaching and clinical use of rotary nickel-titanium endodontic instruments: a survey of French dental schools. Int Endod J 2004;37:320-4.
14. Schneider SW. A comparison of canal preparations in straight and curved root canals. Oral Surg Oral Med Oral Pathol 1971; 32:271-5.

15. Walton RE. Histologic evaluation of different methods of enlarging the pulp canal space. J Endod 1976;2:304-11.

16. Abou-Rass M, Frank AL, Glick DH. The anticurvature filing method to prepare the curved root canal. J Am Dent Assoc 1980; 101:792-4.

17. Tachibana H, Matsumoto K. Applicability of X-ray computerized tomography in endodontics. Endod Dent Traumatol 1990;6: 16-20.

18. Gambill JM, Alder M, Del Rio CE. Comparison of nickel-titanium and stainless steel hand-file instrumentation using computed tomography. J Endod 1996;22:369-75.

19. Rhodes JS, Ford TR, Lynch JA, Liepins PJ, Curtis RV. A comparison of two nickel-titanium instrumentation techniques in teeth using microcomputed tomography. Int Endod J 2000;33:279-85.

20. Garip Y, Günday M. The use of computed tomography when comparing nickel-titanium and stainless steel files during preparation of simulated curved canals. Int Endod J 2001;34: 452-7.

21. Bergmans L, Van Cleynenbreugel J, Beullens $M$, Wevers $M$, Van Meerbeek B, Lambrechts P. Smooth flexible versus active tapered shaft design using $\mathrm{Ni}-\mathrm{Ti}$ rotary instruments. Int Endod J 2002;35:820-8.

22. Hübscher W, Barbakow F, Peters OA. Root-canal preparation with FlexMaster: canal shapes analysed by micro-computed tomography. Int Endod J 2003;36:740-7.

23. Lloyd A, Jaunberzins A, Dhopatkar A, Bryant S, Dummer PM. Shaping ability of the M4 handpiece and Safety Hedstrom files in simulated root canals. Int Endod J 1997;30:16-24.

24. Grano de Oro Cordero E, Gómes Lago J, Azabál Arroyo M, Ruiz de Termiño Malo P. Deformación del conducto radicular tras la instrumentación con limas K-Flexofile y Safety Hedströem utilizando la pieza de mano Safety M4. Endod 1997;15:192-201.

25. Fabra Campos H, Vejarano Pastora J. Digitalización, análisis y procesamiento de imágenes dentales da la preparación de los conductos, efectuada con el sistema mecánico M4 (Kerr). Endod $1999 ; 17: 25-34$.

26. Peters $\mathrm{OA}$, Peters $\mathrm{Cl}$, Schönenberger K, Barbakow F. ProTaper rotary root canal preparation: effects of canal anatomy on final shape analyzed by micro CT. Int Endod J 2003;36:86-92. 